\title{
Citizenship Learning in the Global Era Based on Local Wisdom
}

\author{
$1^{\text {st }}$ Deny Setiawan ${ }^{1}, 2^{\text {nd }}$ Jamaludin $^{2}, 3^{\text {rd }}$ Halking $^{3}$ \\ \{denysetiawan1978@gmail.com ${ }^{1}, *$, jamaludin.unimed.ac.id ${ }^{2}$, halking123@ unimed.ac.id ${ }^{3}$ \} \\ Department of Pancasila and Civic Education, Faculty of Social Sciences, Universitas \\ Negeri Medan, Indonesia 1,2,3
}

\begin{abstract}
The aim of the research is to create the textbook of civic education in the era of global -based to the wisdom of the local. The research method used is the R\&D method by following the Borg \& Gall procedure. This subject of this study involved are lecturers who teach in Citizenship Education Subject, students as subjects for a limited group trial, and three experts for the validation of teaching materials that have some different experts criteria in the subject of Pancasila and Citizenship Education including political, law, and moral experts. In addition learning, Indonesian language and teaching material design expert. The instrument used is an expert validation questionnaire. The research result show that the textbook as product research are very valid and suitable to be used for Citizenship Education Subject as a main subject at Department of Pancasila and Citizenship Education, Social Science Faculty, in Universitas Negeri Medan.
\end{abstract}

Keywords: Citizenship learning, global era, local wisdom.

\section{Introduction}

Indonesia is an archipelagic country which has around 17,667 islands. Among the thousands of islands scattered within the sovereign territory of the Republic of Indonesia, there are more than 700 ethnic groups with their respective cultures. Thus, the identity of Indonesia Nation is inseparable from the existence of Indonesia Nation that diversity. Therefore, the identity of the Indonesian nation is closely related to ethnic identity which is the foundation stone of the Indonesian nation (Tilaar, 2007: XVI). Associated with the ethnic of identity, (Suhartini, 2009) added that most of the ethnic groups in this country have rules known as local wisdom. This statement shows that each ethnic and tribal in Indonesia has its own local wisdom, which at the same time illustrates how rich Indonesia is in the possession of local wisdom.

Suswandari (2017), explains that local wisdom is a distinctive cultural expression which contains values, ethics, norms, rules and skills of a community in meeting sustainability challenges. The values contained in local wisdom have proven to be beneficial for local communities throughout the archipelago who live full of balance and peace. Local wisdom is a product of past cultures that have been traditional and institutionalized as a way of life from generation to generation and become part of the culture. Therefore, Kartawinata (2011) states that local wisdom as local knowledge (indigenous or local knowledge) or local intelligence (local genius) can be used as Indonesian national cultural identity. 
However, along with the changing times, the era of globalization which has an impact on the rise of global values such as: capitalistic, individualistic and hedonistic has shifted local values and increasingly distanced the nation's children from the perspective of their local wisdom and even lost their identity (Latif, 2013). . The phenomenon of this problem needs serious attention from all components of the nation, including educational institutions. Through this institution, the next generation of the nation should in the global era return to having the noble values of the nation's culture. Thus, it is necessary to have concern from elitists, decision makers and education experts to sit together to formulate a national education design that can accommodate the noble values of the nation's culture that can be raised and used as cultural capital as one of the competencies for the nation's generation in competing. in the global era. In this case Atmodjo (1986:37) states that local wisdom can be used as a medium for the nation's ability to deal with the influence of foreign cultures that come to be done selectively. Added by Yunus (2014: 37), local wisdom in a society contains values that can be used as a means of building national character in the face of globalization.

Entering the 76th anniversary of the independence of the Republic of Indonesia, nation and character building as an initial commitment to development, including development in the field of education, has not yet produced optimal results. Various problems that have hit the nation lately in the global era, are suspected to have distanced the nation's generation from good character (Lickona, 1991). Even what is worrying in the lives of today's young generation in the global era, the phenomenon of westernization seems to show that the nation's children are starting to be uprooted from their national roots, hedonistic lifestyles, free lifestyles, pornography, drug addiction, brawls, bullying, hoaxes, and even radicalism. The fact that the post-reform national character is increasingly concerning, it is appropriate for all components of the nation and existing institutions to commit to placing nation and character building as the main priority in development. The existence of institutions, including educational institutions, is very much needed and has an important role as a forum for strengthening national character [1]. Therefore, within the framework of nation character building, it is appropriate for educational institutions in the global era to act as a forum in the formation of national character through strengthening the values of local wisdom. In this regard, this research tries to develop global citizenship learning based on insightful local wisdom as a systemic program to strengthen national character. This idea emerged against the background of the fact that civic education in universities is not yet optimal, which contextually can utilize local wisdom to its students in the development of national character, which at the same time equips graduates with the values of local wisdom as cultural capital to be competitive in the global era.

\subsection{Citizenship Learning in the Era of Global Based on Local Wisdom}

In the current transition period, where the nation's journey is towards civil society. The subject of Citizenship Education is as one of the subjects in schools and as a subject in universities. It is deemed necessary to be able to adapt to the needs and demands of a changing society in the global era. The process of national character building which has been built since the independence era, needs to be revitalized so that it is in accordance with the contents of the constitutional message. The revitalization process of the national character building referred to at this time is directed at the creation of an Indonesian society order that places democracy as the central point in the life of the nation and state (Print, 1999: 25). Citizenship education in the reform era in the global era must be able to shift its paradigm from a feudalistic one to a new paradigm that shows New Indonesian Civic Education (Winataputra, 2009: 1). 
The global trend of civic education is also stated by John J. Patrick (Quiqley, 2000: 4 - 7) as a study figure who presents himself as an educational program that examines the functional relationship between civic knowledge, skills in social life in society (Civic skills) and the development of virtue values in society (Civic Virtue). The knowledge of citizenship in question concerns the principles and theories of democracy, the running of a democratic government and the democratic behavior of the people as well as the comparison of democratic values between countries. This understanding will then direct students as citizens to have the knowledge and skills of citizens, which are then supported by the values of virtue in their society, including the noble values of their nation's culture. Thus, the competence of citizens in the global era in addition to their ownership of civic knowledge and civic skills, needs to be well equipped with the competence of civic virtue that ownership of the values of virtue that comes from the noble values of the community, to be able to perform as a global citizen of a democratic but without left the national identity.

Therefore, civic education is with its new paradigm in the global era, it is necessary to redesign the study of subject matter that can equip students to be prepared as global citizens with ownership of local cultural values as cultural capital in order to be competitive in the global era for the progress of the nation. The phrase "think globally act locally" from John Naisbitt and Patricia Aburdene [2] has actually hinted at this, by showing the globalizing trend in the 21 st century to prepare global citizens who are full of paradoxes between the struggle for global values and local values. Facts show that the era of globalization with the hegemony of global values has marginalized local values. Globalization in addition to having an impact on progress, but on the other hand gives birth to global citizens who forget local values as their national identity.

In the era of globalization, the national character becomes the focus of attention along with the acculturation of cultures between countries. The original characters of the region become the right tool in instilling the values of local wisdom in the next generation of the nation. The values of local wisdom need to be revitalized to actualize the nation's identity with socio-cultural values. In accordance with existing regulations, civic education in the scope of formal education, both as a subject at the school level and as a subject at universities focuses on the formation of citizens who understand and are able to carry out their rights and obligations to become intelligent Indonesian citizens, skilled, and have character as mandated by Pancasila and the 1945 Constitution. These limitations indicate that Citizenship Education is an educational process, not only teaching or transferring knowledge, but also includes attitudes to shape character and personality. The scope of local wisdom material in civics learning is expected to be able to instill the character of love for local wisdom in students [3].

The study of the problems of local collective awareness and national identity in the era of globalization is very relevant in the discourse. This fact is in line with the various changes that occur in the life of society, nation and state after the reformation which demands changes in almost all aspects of life. Such demands often trigger crucial problems, so that they can threaten the integrity of the life of society, nation and state. Therefore, in facing all forms of change including changes in values in the life of society and the nation, local wisdom becomes an important cultural element to continue to be explored, studied, and revitalized as an important essence in strengthening the foundation of national identity in facing the challenges of globalization [4].

Local culture faces serious threats in the era of globalization. In this era, the rapid development of information and communication technology has transferred Western culture to developing countries, including Indonesia. The problem is that foreign cultures that come from outside are not always in accordance with the basic values adopted by the Indonesian 
people. The phenomenon of hegemony of cultural values in the era of globalization, has shown that local values are increasingly marginalized which has an impact on the occurrence of a local cultural crisis. Therefore, local culture must have the ability to contain some of the changes brought about by the globalization process. It is necessary to formulate a strategy in solving this problem to save the local culture from extinction. Global threats to local cultural values need to be anticipated through the implementation of appropriate strategies, namely by revitalizing actions to protect local cultures [5].

In the current era of globalization, where the identity of a nation is being tested, building national character is a must. This is the reason, the importance of building national character not only at home or school, but also in society. In particular, the community as a center for character education, through the daily practice of the community in utilizing the values of local wisdom, can be used as learning for the younger generation in growing their national identity. Like the Malays of West Kalimantan, who have local wisdom, which is still firmly grasped in their daily lives as Malays. The local wisdom held by the Malays of West Kalimantan is very close to Islam, considering the connection between Malay and Islamic identities. This local wisdom is born, grows and develops among the Malays of West Kalimantan and is of hybrid color, because there is a blend of local wisdom with Islamic values [6].

Indonesia is a nation with a diverse culture based on different communities based on ethnicity and race. On the one hand, this diversity is a very valuable treasure that has been inherited and has become the identity of its owner, but on the other hand it can be a factor that triggers division. Therefore, what is believed to be the cultural heritage of a community, needs to be interpreted in terms of the national cultural heritage as well. Therefore, in the context of national cultural development, local cultural values that are increasingly marginalized in the global era need to be revitalized [7]. In this case, educational institutions are one of the important institutions in revitalizing local cultural values through the formulation of their curriculum in building the character of the nation's next generation. The development of a national curriculum containing character is formulated comprehensively covering components, elements, objectives, functions, principles, and character values [8]. Furthermore, the development of character learning can be carried out effectively by integrating the values of local wisdom [9]. At the regional or local level, the character education approach should be applied contextually, using local wisdom to build understanding and skills and attitudes of students to respect each other's differences in cultural values, ethnic origins and ethnicities according to local conditions [10].

Likewise for civic education as a subject in schools and as a subject in universities, it is deemed necessary to be able to adapt to the needs and demands of a changing society in the global era. According to John J. Patrick (Quiqley, 2000: 4-7), Citizenship Education as an educational program in the global era must be able to functionally display civic knowledge, skills in social life in society (civic skills) and the development of values of virtue in society (civic virtue). Therefore, civics learning in the global era is deemed necessary to be designed by redesigning material studies that can equip students with two things, namely: preparing students as global citizens to have competitiveness in order to be competitive in the global era; and have a national character by appreciating local cultural values as their national identity.

\section{Method}


This research was conducted at the Department of Pancasila and Citizenship Education, Faculty of Social Sciences, State University of Medan, which is located at Jalan Williem Iskandar Pasar V Medan Estate. The research subjects include: a lecturer in Citizenship Education courses; students as a limited trial group; and six validation experts consisting of: three Citizenship Education experts (including: political experts, legal experts, moral experts), one learning expert, one textbook design expert, and one Indonesian language expert.

This study applies the R\&D development research model from Borg \& Gall which in its implementation follows the following procedure.

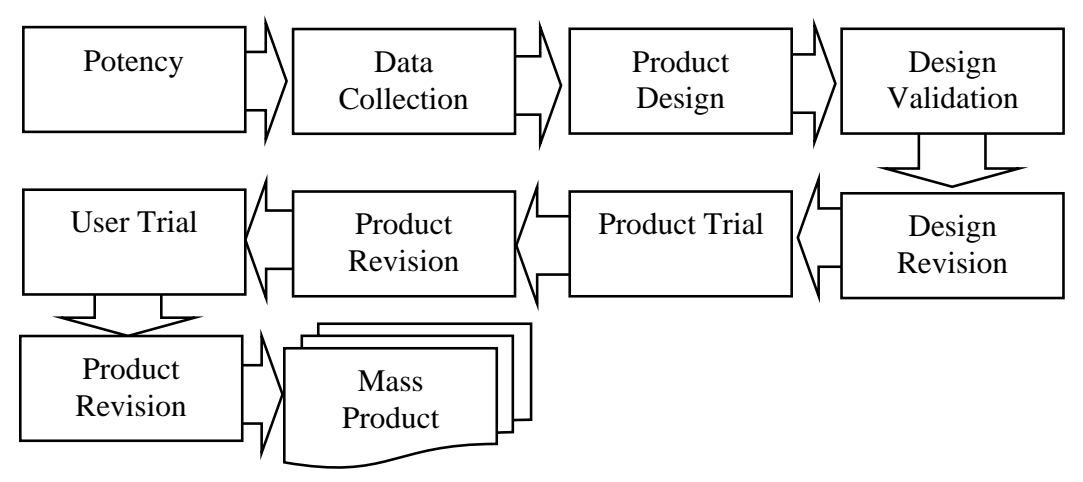

Fig. 1. Research procedure (source: Sugiyono, 2017)

The instrument used in this study was an expert validation questionnaire. The expert validation questionnaire instrument used a Likert scale modified by the researcher into a scale of 4 . The assessment criteria were classified at four levels with the following ratings: (1) Not good, (2) Good enough, (3) Good, (4)Very good, Sudjana (2007:1006). While the textbook questionnaire uses the Guttman scale, which is a measurement scale with firm answers, namely: yes-no, true-false, never-never, positivenegative (Sugiyono, 2017). The grid of expert validation questionnaires is presented in the following table:

Table 1. Expert validation questionnaire grid.

\begin{tabular}{|c|c|c|}
\hline No & Component & Sub-component \\
\hline $\mathrm{I}$ & Content eligibility & $\begin{array}{l}\text { a. The suitability of the material description with learning } \\
\text { outcomes } \\
\text { b. Material accuracy } \\
\text { c. Material updates } \\
\text { d. Drives curiosity }\end{array}$ \\
\hline II & Serving eligibility & $\begin{array}{ll}\text { a. } & \text { Presentation technique } \\
\text { b. } & \text { Learning support } \\
\text { c. } & \text { Coherence and Regularity groove think }\end{array}$ \\
\hline III & Language Eligibility & $\begin{array}{ll}\text { a. } & \text { Accurate } \\
\text { b. } & \text { Communicative } \\
\text { c. } & \text { Suitability }\end{array}$ \\
\hline IV & Feasibility teaching book & $\begin{array}{l}\text { a. The story continues chapter to chapter } \\
\text { b. Contextual } \\
\text { c. conclussing and interesting story }\end{array}$ \\
\hline
\end{tabular}


Data analysis was carried out on the validation of global citizenship learning based on local wisdom in the Department of Pancasila and Citizenship Education, Faculty of Social Sciences, State University of Medan which was developed in the form of a textbook. To analyze the results of the assessment given by the experts on the quality and feasibility of the product, the following Percentage Average Score (PRS) formula is used:

\begin{tabular}{|c|c|c|c|c|c|c|c|}
\hline \multicolumn{8}{|c|}{$\begin{array}{l}\text { PRS }=\frac{\text { Total Score }}{\text { Max Score }} \times 100 \% \text { (Sudjana, 2007:129) } \\
\text { With Criteria: }\end{array}$} \\
\hline $90 \%$ & $\leq$ & PRS & $\leq$ & $100 \%$ & $=$ & Very Good & $(\mathrm{S}$ \\
\hline $80 \%$ & $\leq$ & PRS & $\leq$ & $90 \%$ & $=$ & Good & (B) \\
\hline $70 \%$ & $\leq$ & PRS & $\leq$ & $80 \%$ & $=$ & Enough & (C) \\
\hline $60 \%$ & $\leq$ & PRS & $\leq$ & $70 \%$ & $=$ & Less & $(\mathrm{K})$ \\
\hline $0 \%$ & $\leq$ & PRS & $\leq$ & $60 \%$ & $=$ & Very Less & (SF \\
\hline
\end{tabular}

\section{Result and Discussion}

In the first stage, Introduction research was conducted. Based on interviews conducted with lecturers who support the Citizenship Education course, information is obtained, the content of the Citizenship Education material makes an important contribution to the profile of graduates and the learning outcomes of graduates which include competencies: knowledge, skills and attitudes. However, from the observations it was found that Citizenship Education, which should be implemented in an integrated manner, still tends to be delivered separately and not simultaneously. The civics learning process tends to be dominant in the realm of knowledge by presenting material and information widely, but there is little time to train students' skills, especially in solving problems related to citizenship issues. While the domain of attitudes as an important part for the internalization of values tends to be conveyed verbally. According to Branson [11], the civics learning process should be developed by covering three interrelated components, namely: civic knowledge, civic skills, and civic disposition. Therefore, it is deemed necessary to develop citizenship education learning in an integrated and simultaneous manner. This is done so that civic education in the global era can develop civic competence as a whole (civic competence), desirable personal qualities, civic culture and democratic values and beliefs towards the formation of a personality that has a sense of community and national responsibility (Winataputra, 2002). In this national context, it is deemed necessary to develop civics learning in the global era by utilizing local wisdom values as a program to strengthen the national character for student.

Based on the results of preliminary research in the first stage of this research, the development of civics learning needs to be complemented by the existence of textbooks as research products. The design of the textbook was carried out in the second stage of this research, by developing the formulation of Civic Education learning outcomes through the development of civic education subject matter and integrating it with the concept of local wisdom and the concept of national character as presented in the following table.

Table 2. Learning outcomes learning citizenship education. 


\begin{tabular}{|c|c|}
\hline Material & Learning Outcomes \\
\hline $\begin{array}{l}\text { The Nature of Global } \\
\text { Citizenship Education }\end{array}$ & $\begin{array}{l}\text { Students can understand and show a critical attitude while study "Hakikat Pendidikan } \\
\text { Kewarganegaraan Global" subject which includes the concepts of: } \\
\text { 1. Definition and Objectives of Citizenship Education } \\
\text { 2. Scope of Citizenship Education } \\
\text { 3. Characteristics of Global Citizenship Education }\end{array}$ \\
\hline $\begin{array}{l}\text { Components of } \\
\text { Citizenship Education } \\
\text { in the Global Era }\end{array}$ & $\begin{array}{l}\text { Students can understand showing a critical attitude while studying the material for } \\
\text { "Komponen Pendidikan Kewarganegraan Di Era Global" which includes the following } \\
\text { components: } \\
\text { 1. Civic Knowledge } \\
\text { 2. Civic Skills } \\
\text { 3. Civic Disposition }\end{array}$ \\
\hline $\begin{array}{l}\text { Citizenship Education } \\
\text { as a National Character } \\
\text { Development Program }\end{array}$ & $\begin{array}{l}\text { Students can understand and demonstrate a critical attitude and are able to apply the } \\
\text { concepts and the theories while study "Pendidikan Kewarganegaraan Sebagai Program } \\
\text { Pengembangan Karakter Kebangsaan" which includes, the concepts of : } \\
\text { 1. Citizenship Education in Indonesia } \\
\text { 2. Citizenship Education in Global Dimension } \\
\text { 3. National Character }\end{array}$ \\
\hline $\begin{array}{l}\text { Content of Local } \\
\text { Wisdom in Learning } \\
\text { Global Citizenship }\end{array}$ & $\begin{array}{l}\text { Students can understand and demonstrate a critical attitude and are able to apply concepts } \\
\text { and theories while study "Muatan Kearifan Lokal dalam Pembelajaran } \\
\text { Kewarganegaraan Global" which includes the concepts of: } \\
\text { 1. Concept of Local Wisdom } \\
\text { 2. Utilization of Local Wisdom Values in Citizenship Learning }\end{array}$ \\
\hline $\begin{array}{l}\text { Citizenship Learning } \\
\text { Design Based on Local } \\
\text { Wisdom }\end{array}$ & $\begin{array}{l}\text { Students are able to understand and demonstrate a critical attitude and be able to apply the } \\
\text { concept and theory for studying "Desain Pembelajaran Kewarganegaraan Berbasis } \\
\text { Kearifan Lokal" which including, Concept; } \\
\text { 1. Innovative Citizenship Learning } \\
\text { 2. Citizenship Learning Containing Local Wisdom Values as a Program for } \\
\text { Strengthening National Character }\end{array}$ \\
\hline $\begin{array}{l}\text { Project Citizen Based } \\
\text { on Local Wisdom }\end{array}$ & $\begin{array}{l}\text { Students can understand and demonstrate a critical attitude and are able to apply concepts } \\
\text { and theories while studying "Project Citizen Based on Local Wisdom" which includes, } \\
\text { the concepts of : } \\
\text { 1. Project Citizen in Citizenship Learning } \\
\text { 2. Project Activities With Local Wisdom Values }\end{array}$ \\
\hline
\end{tabular}

Product design as shown above, for further evaluation of product development. This stage is the last step in the research. This stage includes evaluation of the validator and testing of small group students. Product testing to experts and the development of this research was carried out through a questionnaire. The validation results are presented as in the following table.

Table 3. Material content expert validation results.

\begin{tabular}{|c|l|l|l|l|}
\hline \multirow{2}{*}{ No } & \multicolumn{1}{|c|}{ Component } & \multicolumn{1}{|c|}{ Indicator } & Score & \multicolumn{1}{c|}{ Category } \\
\hline \multirow{2}{*}{1} & Text (language) & Accurate font selection and font size for easy reading & 4 & Very good \\
\cline { 3 - 5 } & & Text color accuracy for easy reading & 4 & Well \\
\cline { 3 - 5 } & & Language compatibility with enhanced spelling or EYD & 4 & Well \\
\cline { 3 - 5 } & & Communicative & 4 & Well \\
\cline { 3 - 5 } & & The sentence is effective & 4 & Enough \\
\hline
\end{tabular}




\begin{tabular}{|c|c|c|c|c|}
\hline \multicolumn{3}{|c|}{ Total score of the text or typographic component (language) } & 20 & \\
\hline \multicolumn{3}{|c|}{ Average } & 4 & Well \\
\hline \multirow[t]{14}{*}{2} & \multirow[t]{14}{*}{ Contents } & Materials, tables and figures are clearly visible & 4 & Well \\
\hline & & Easy-to-understand materials, tables and figures & 3 & Enough \\
\hline & & $\begin{array}{l}\text { The material contains elements of local wisdom } \\
\text { substance }\end{array}$ & 5 & Very good \\
\hline & & Rigid material in the discussion of character values & 5 & Very good \\
\hline & & $\begin{array}{l}\text { The suitability of the material with the learning } \\
\text { achievement of the subject }\end{array}$ & 5 & Very good \\
\hline & & The material is presented clearly and coherently & 5 & Very good \\
\hline & & Material accuracy & 5 & Very good \\
\hline & & Material up-to-date & 4 & Well \\
\hline & & Material depth & 5 & Very good \\
\hline & & Material breadth & 4 & Well \\
\hline & & $\begin{array}{l}\text { The accuracy of the selection of case examples with the } \\
\text { material }\end{array}$ & 5 & Very good \\
\hline & & $\begin{array}{l}\text { The accuracy of the selection of supporting literature } \\
\text { with the material }\end{array}$ & 4 & Well \\
\hline & & Materials encourage curiosity & 5 & Very good \\
\hline & & The suitability of the material with the student's character & 4 & Well \\
\hline \multicolumn{3}{|c|}{ Total content component score } & 63 & \\
\hline \multicolumn{3}{|c|}{ Average } & 4,5 & Well \\
\hline \multirow[t]{2}{*}{3} & \multirow[t]{2}{*}{ Supporting literature } & Ease of accessing supporting literature & 4 & Enough \\
\hline & & Composition of supporting literature & 4 & Very good \\
\hline \multicolumn{3}{|c|}{ Total navigation component score } & 8 & \\
\hline \multicolumn{3}{|c|}{ Average } & 4 & Well \\
\hline \multirow[t]{2}{*}{4} & \multirow[t]{2}{*}{ User } & Media according to user characteristics & 5 & Very good \\
\hline & & Flexibility & 4 & Well \\
\hline \multicolumn{3}{|c|}{ Total user component score } & 9 & \\
\hline \multicolumn{3}{|c|}{ Average } & 4,5 & Well \\
\hline \multicolumn{3}{|c|}{ Total Score Rating } & 100 & \\
\hline \multicolumn{3}{|c|}{ Average } & 4.3 & Well \\
\hline
\end{tabular}

Based on the table above, the content of global citizenship education materials based on local wisdom developed from the results of this study obtained an average score of 4.3 with details: the text component got a score of 4; the content component scored 4.5; the supporting literature component scored 4; and the user component scored 4.5. The total average score for all components reached 4.3 or was in the "Good" category. Thus, the textbooks developed in this study deserve to be tested without having to make revisions. While the assessment criteria in percentage terms have reached $85 \%$ or can be declared valid as shown in the following table.

Table 4. Validation test results.

\begin{tabular}{|l|l|l|l|}
\hline Validator & $\begin{array}{c}\text { Material content } \\
\text { expert }\end{array}$ & Validation & Criteria \\
\hline
\end{tabular}




\begin{tabular}{|l|c|c|l|}
\hline $\begin{array}{l}\text { Material and } \\
\text { Language Expert }\end{array}$ & 1 & $83 \%$ & Valid/Not Revised \\
\hline $\begin{array}{l}\text { Material and } \\
\text { Language Expert }\end{array}$ & 2 & $85 \%$ & Valid/Not Revised \\
\hline $\begin{array}{l}\text { Material and } \\
\text { Language Expert }\end{array}$ & 3 & $84 \%$ & Valid/Not Revised \\
\hline $\begin{array}{l}\text { Material and } \\
\text { Language Expert }\end{array}$ & 4 & $86 \%$ & Valid/Not Revised \\
\hline Average & & $85 \%$ & Valid/Not Revised \\
\hline
\end{tabular}

The results of the evaluation or trial of a small group of research products are carried out to assess the feasibility of textbooks on Global Citizenship Education Based on Local Wisdom. The feasibility test questionnaire contains three aspects of the assessment, namely: presentation of material, learning and language. The data obtained from the test results are presented in the following table.

Table 5. User test results

\begin{tabular}{|c|c|c|c|c|c|}
\hline No & Aspect & No. Item & Indicator & Average Score & Category \\
\hline \multirow[t]{5}{*}{1} & \multirow[t]{5}{*}{ Material } & 1 & $\begin{array}{l}\text { The material in the } \\
\text { textbook is easy to } \\
\text { understand }\end{array}$ & 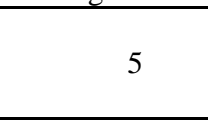 & Very good \\
\hline & & 2 & $\begin{array}{l}\text { The material is presented } \\
\text { clearly and coherently }\end{array}$ & 4,6 & Very good \\
\hline & & 3 & $\begin{array}{l}\text { The material presented is } \\
\text { useful in lectures }\end{array}$ & 4,8 & Very good \\
\hline & & 4 & $\begin{array}{l}\text { The material is discussed in } \\
\text { depth }\end{array}$ & 5 & Very good \\
\hline & & 5 & $\begin{array}{l}\text { The source or literature is } \\
\text { clear and easily accessible }\end{array}$ & 4,4 & Very good \\
\hline \multicolumn{4}{|c|}{ Average score of material aspect } & 4,8 & Very good \\
\hline \multirow[t]{2}{*}{2} & \multirow[t]{2}{*}{ Learning } & 6 & Encourage curiosity & 5 & Very good \\
\hline & & 7 & Increase interest in learning & 4,2 & Very good \\
\hline \multicolumn{4}{|c|}{ Average score of learning aspect } & 4,6 & Very good \\
\hline \multirow[t]{2}{*}{3} & \multirow[t]{2}{*}{ Language } & 8 & Communicative & 5 & Very good \\
\hline & & 9 & $\begin{array}{l}\text { Language compatibility } \\
\text { with EYD }\end{array}$ & 4,6 & Very good \\
\hline \multicolumn{4}{|c|}{ Average score of language aspect } & 4,7 & Very good \\
\hline \multicolumn{4}{|c|}{ Average score } & 4,68 & Very good \\
\hline
\end{tabular}

The table above shows that the testing phase of the product is in the Very Good category. Shown by the data: the average score for the material aspect is 4, 7 with the category "Very Good"; the average score for the learning aspect is 4, 6 with the category "Very Good"; da n aspects of the language to get an average score of 4, 7 with the category of "Very Good".

The average score for the three aspects assessed in this first trial reached 4.68 in the "Very Good" category. Based on the results of product feasibility trials from users, there were no fundamental deficiencies in the product, both in terms of material, learning and language. The Citizenship Education Book Based on Local Wisdom as a systemic program for the 
cultivation of national character values can be stated as very good with the percentage of assessment reaching $94.6 \%$. These data indicate that the textbook as a product in this research, is very feasible to use and can be used as a guide for lecturers and students in learning Citizenship Education as a core course in the Department of Pancasila and Citizenship Education.

Overall, the research results show that textbooks as research products meet the elements of validity and feasibility. Based on the results of data processing both from observations, interviews and questionnaires, the elements of the feasibility of textbooks have been met because the content of the developed global citizenship education material is well-structured and includes three interrelated components, namely: civic knowledge, civic skills, and civic disposition [11]. The results also show that the presentation of material in the learning process of civic education has been carried out in an integrated and simultaneous manner which shows the interrelationships between the components of knowledge, skills and attitudes, so that they can contribute to the fulfillment of student competence (civic competence) and the learning objectives of Citizenship Education in the global era. Namely forming reliable citizens for themselves, society, nation and state. The purpose of civic education in the global era is not only to form a good citizenship which is dominant in the realm of attitudes, but more broadly to form citizens who meet the expectations of desirable personal qualities with the possession of knowledge, attitude, and skill competencies, so that students as citizens have the power competitiveness to be competitive in the global era.

On the other hand, the feasibility of this civics education textbook is not only designed to fulfill the globalizing element (global citizenship education), it is also designed to contain the localizing element (civic education based on local wisdom). The design of global citizenship education is designed with the aim of forming students as citizens who meet the expectations of desirable personal qualities so that they can have competitive competitiveness in the global era. While the design of civic education based on local wisdom is designed with the aim of forming reliable citizens for themselves, the nation and the state and having social and national moral responsibility (Winataputra, 2002). The integration of globalizing and localizing elements in the content of this textbook is expected to support civic education as a program to strengthen national character. Thus, the textbook for global citizenship education based on local wisdom developed in this study is aimed at strengthening student competencies into three aspects, namely: knowledge aspect, ability to appreciate the noble values of national culture in the form of local wisdom as national identity; aspects of skills, the ability to utilize the values of local wisdom to serve as cultural capital in strengthening its competitiveness in the global era; and aspects of attitude, the ability to position oneself as a global citizen who is proud of the noble values of his nation's culture. 


\section{References}

[1] Setiawan D. Kontribusi Tingkat Pemahaman Konsepsi Wawasan Nusantaraterhadap Sikap Nasionalisme dan Karakter Kebangsaan. JUPIIS: Jurnal Pendidikan Ilmu-ilmu Sosial. 2017; Vol. 9 (1): 20-33.

[2] Alimin A. Sepuluh Arah Baru Untuk Tahun 1990-an Karya: John Naisbitt \& Patricia Aburdene. Jakarta. Bina Rupa Aksara; 1990

[3] Totok T. Pembelajaran Pendidikan Pancasila dan Kewarganegaraan Berbasis Kearifan Lokal untuk Penguatan Karakter dan Jati Diri Bangsa. In: Konferensi Nasional Kewarganegaraan III; 11 November 2017; Universitas Ahmad Dahlan Yogyakarta, Indonesia: 400-408.

[4] Brata IB. Kearifan budaya lokal perekat identitas bangsa,. Jurnal Bakti Saraswati (JBS). 2016; 5 (1): 9-16.

[5] Mubah AS. Strategi meningkatkan daya tahan budaya lokal dalam menghadapi arus globalisasi. Jurnal Unair. 2011; 24 (4), Hal. 302-308.

[6] Kurniawan S. Globalisasi, Pendidikan Karakter, dan Kearifan Lokal yang Hybrid Islam pada Orang Melayu Kalimantan Barat. Jurnal Penelitian. 2018; 12 (2): 317-354

[7] Handayani PM. Kearifan lokal sebagai pil pahit pencegah penyakit globalisasi. In: pibsi xxxix. Semarang: 7-8 november; 2017.

[8] Julaeha S. Problematika Kurikulum Dan Pembelajaran Pendidikan Karakter. Jurnal Penelitian Pendidikan Islam,[SL]. 2019; 7 ( 2): 157-182

[9] Nadlir M. Urgensi pembelajaran berbasis kearifan lokal. Jurnal Pendidikan Agama Islam . Journal of Islamic Education Studies. 2011; 2 (2): 299-330

[10] Amirin, T. M.. Implementasi pendekatan pendidikan multikultural kontekstual berbasis kearifan lokal di Indonesia. Jurnal pembangunan pendidikan: Fondasi dan aplikasi. 2011; Vol. 1(1): 1-16.

[11] Branson M.S, et al. Belajar Civic Education dari Amerika. Yogyakarta: LKIS; 1999. 